\title{
Cancer risk among Danish and Italian farmers
}

\author{
Guglielmo Ronco, Giuseppe Costa, Elsebeth Lynge
}

\begin{abstract}
Cancer risk for farmers in Denmark and Italy was studied by linking occupational census data with incidence of cancer in Denmark and with cancer mortality in Italy. Farmers in the two countries had a consistent risk reduction for cancer of the lung, bladder, small intestine, colon, rectum, and prostate. No excess of stomach cancer was found among farmers in the two countries, which is in agreement with the most recent data from other surveys. The risk of oesophageal cancer was reduced among the Danish and increased among the Italian male farmers. This can probably be explained by differences in alcohol consumption between the Danish and Italian farmers compared with the general population. The risk of brain cancer was significantly reduced among Italian farmers. There was a significant risk reduction for Hodgkin's disease and no excess for nonHodgkin's lymphoma in Denmark, whereas in Italy a statistically significant excess risk was found for the first and a slight excess risk for the second of these diseases. The per capita consumption of phenoxy-herbicides between 1950 and 1970 was lower in Italy than in Denmark but treatments were performed mainly by professional applicators in Denmark and by the farmers themselves in Italy. Risk of leukaemia among Italian female farmers was increased. In Denmark, this increase was limited to women who were themselves owners of a farm. Specific occupations in agriculture showing a high risk for cancers of the lymphopoietic system in Denmark mostly entailed contact with animals.
\end{abstract}

Unit of Cancer Epidemiology, Department of Oncology, Ospedale S Giovanni AS, via S Francesco da Paola 31, 10123 Turin, Italy

G Ronco

Unit of Epidemiology, USL TOI, via S Francesco da Paola 31, 10123 Turin, Italy

G Costa

Danish Cancer Society, Danish Cancer Registry, Rosenvaengets Hovedvej 35, Box 839, DK-2100 Copenhagen Ø, Denmark

E Lynge
Farmers are a group known to be at low overall risk of cancer and to have low overall mortality. The low risk of cancer is the result of a low frequency among farmers of the most common cancer sites, like lung cancer and colon cancer. An excess risk among farmers has, however, been reported for stomach cancer and for some, generally uncommon, cancer sites.

Findings from different countries are, however, conflicting and both the reasons for the deficits and the exposures responsible for the excesses are not understood. Moreover, reports are available only from a limited number of countries where surveillance systems based on routine records have been running for many years, such as North America, New Zealand, England and Wales, and Nordic Countries. Only a few studies on specific cancer sites among farmers in Southern Europe are available.

Recently Italian mortality data have been experimentally linked with census data to describe socioeconomic differentials in mortality. This has provided the opportunity of comparing the cancer risk among farmers in a Nordic country and in a Mediterranean country. Both the lifestyle of farmers and the agricultural activities show important differences between these countries and the comparison can thus provide further insight into the peculiar cancer risk profile of farmers.

\section{Materials and methods}

\section{COHORTS AND CANCER CASES}

A cohort of farmers of both sexes, 15 to 74 years old, was identified from the Danish Occupational Cancer Register for a 10 year follow up study of cancer incidence in the 1970 census population. Occupation was coded according to a special Danish nomenclature. For the present study two broad categories of farmers (self employed and employees) were considered for men and three (self employed, family workers, and employees) for women. A women was defined as a family worker if she was actively involved in the work of a farm owned by her husband. Detailed groups defined by specific occupations were also considered for cancers of the lymphopoietic system.

The cancer cases in the Danish cohort were identified through the record linkage between the 
Table 1 Standardised incidence ratios (SIRs) and mortality odds ratios (MORs) of cancer among male Danish and Italian farmers

\begin{tabular}{|c|c|c|c|c|c|c|c|c|c|c|c|}
\hline \multirow[b]{3}{*}{ Cancer sites } & \multicolumn{4}{|c|}{ Denmark } & & \multicolumn{6}{|l|}{ Italy } \\
\hline & \multicolumn{2}{|c|}{ Self employed } & \multicolumn{2}{|c|}{ Employees } & & \multicolumn{3}{|c|}{ Self employed } & \multicolumn{3}{|c|}{ Employees } \\
\hline & Obs & SIR & Obs & SIR & & Obs & $M O R$ & $\begin{array}{l}\text { Adjusted } \\
M O R\end{array}$ & Obs & $M O R$ & $\begin{array}{l}\text { Adjusted } \\
\text { MOR }\end{array}$ \\
\hline Lip & 182 & $1 \cdot 80^{\star}$ & 43 & $2 \cdot 09$ * & & & & & & & \\
\hline Tongue & 9 & 0.58 & 2 & 0.63 & & & & & & & \\
\hline Salivary glands & 13 & 0.92 & 0 & 0.00 & & 13 & $1 \cdot 14$ & 0.91 & 4 & 0.62 & $0 \cdot 50$ \\
\hline $\begin{array}{l}\text { Mouth } \\
\text { Pharynx }\end{array}$ & 14 & $\begin{array}{l}0.47^{\star} \\
0.32 \star\end{array}$ & 0 & $0 \cdot 00^{\star}$ & & & & & & & \\
\hline $\begin{array}{l}\text { Pnarynx } \\
\text { Oesophagus }\end{array}$ & $\begin{array}{l}13 \\
32\end{array}$ & $\begin{array}{l}0.32^{\star} \\
0 \cdot 44^{\star}\end{array}$ & $\begin{array}{r}9 \\
13\end{array}$ & $\begin{array}{l}1 \cdot 10 \\
0.92\end{array}$ & & 15 & $1 \cdot 81^{\star}$ & 1.45 & 5 & 1.08 & 0.86 \\
\hline Stomach & 286 & 0.94 & 71 & 1.21 & & 66 & 1.25 & 1.00 & 34 & 1.42 & $1 \cdot 14$ \\
\hline Small intestine & 12 & 0.58 & 1 & 0.24 & $\dagger$ & 6 & 0.51 & $0.41^{\star}$ & 2 & $0 \cdot 39$ & $0 \cdot 31$ \\
\hline Colon & 277 & $0 \cdot 70^{\star}$ & 45 & $\begin{array}{l}0 \cdot 58^{\star} \\
0 \cdot 77^{\star}\end{array}$ & & 29 & 0.93 & 0.74 & 7 & $0.46^{\star}$ & $0 \cdot 37^{\star}$ \\
\hline $\begin{array}{l}\text { Rectum } \\
\text { Liver }\end{array}$ & $\begin{array}{r}309 \\
23\end{array}$ & $\begin{array}{l}0.83^{\star} \\
0.37^{\star}\end{array}$ & $\begin{array}{r}55 \\
9\end{array}$ & $\begin{array}{l}0.77^{\star} \\
0.75\end{array}$ & & & & & & & \\
\hline Gallbladder & 35 & 0.76 & 7 & 0.78 & & 28 & $0 \cdot 86$ & $0 \cdot 69$ & 10 & 0.67 & 0.54 \\
\hline Liver not specified as primary & 13 & 0.85 & 3 & 1.00 & & & & & & & . \\
\hline Pancreas & 137 & $0 \cdot 64^{\star}$ & 23 & $0.55^{\star}$ & & 29 & 1.34 & 1.07 & 12 & $1 \cdot 17$ & 0.94 \\
\hline Peritoneum and unspecified digestive & 18 & $1 \cdot 22$ & 3 & 0.92 & $\ddagger$ & - & - & - & - & - & - \\
\hline Nasal cavities and sinuses & 11 & 0.58 & 5 & $1 \cdot 27$ & & 0 & 0 & 0.00 & 1 & $4 \cdot 15$ & 3.32 \\
\hline Larynx & 38 & $0 \cdot 29 \star$ & 12 & $0 \cdot 47^{\star}$ & & 13 & 1.07 & 0.86 & 4 & 0.69 & 0.55 \\
\hline Lung & 559 & $0 \cdot 40^{\star}$ & 191 & $0 \cdot 72^{\star}$ & & 111 & $0 \cdot 64^{\star}$ & 0.51 * & 67 & $0 \cdot 84$ & $0.67 \star$ \\
\hline Pleura & 10 & $0 \cdot 37^{\star}$ & 3 & $0 \cdot 57$ & & 4 & $1 \cdot 47$ & $1 \cdot 18$ & 0 & 0 & 0.00 \\
\hline Lung not specified as primary & 5 & $0 \cdot 41^{\star}$ & 0 & 0.00 & & - & - & - & - & - & - \\
\hline Mediastinum and unspecified respiratory & 0 & $0 \cdot 00 \star$ & 0 & 0.00 & & 5 & $1 \cdot 81$ & 1.45 & 0 & 0 & 0.00 \\
\hline Breast & 5 & 0.48 & 3 & $1 \cdot 37$ & & - & - & - & - & - & - \\
\hline Prostate & 399 & $0 \cdot 89^{\star}$ & 63 & $0 \cdot 76^{\star}$ & & 10 & 0.9 & 0.72 & 2 & 0.53 & 0.42 \\
\hline Testis & 74 & 0.93 & 23 & $0 \cdot 64^{\star}$ & & - & - & - & - & - & - \\
\hline Other and unspecified genital & 16 & 0.73 & 4 & 0.89 & & - & - & - & - & - & - \\
\hline Kidney & 141 & $0.64^{\star}$ & 18 & $0.41^{\star}$ & & 14 & 1.46 & $1 \cdot 17$ & 2 & $4 \cdot 88$ & 3.90 \\
\hline Bladder & 300 & $0.55^{\star}$ & 70 & $0.65^{\star}$ & & 12 & 0.81 & 0.65 & 2 & 0.34 & 0.27 \\
\hline Melanoma of skin & 72 & $0.67^{\star}$ & 17 & 0.64 & & 6 & 1.43 & $1 \cdot 14$ & 0 & 0 & 0.00 \\
\hline Other skin & 493 & $0.69^{\star}$ & 98 & $0.69^{\star}$ & & - & - & - & - & - & - \\
\hline Eye & 19 & 0.91 & 6 & $1 \cdot 34$ & & - & - & - & - & - & - \\
\hline Brain and nervous system & 194 & 1.06 & 39 & 0.93 & $\S$ & 13 & 0.69 & $0.55^{\star}$ & 7 & 0.71 & 0.57 \\
\hline Thyroid & 13 & $0 \cdot 70$ & 5 & $1 \cdot 13$ & & - & - & - & - & - & - \\
\hline Endocrine glands & 8 & 0.83 & 1 & 0.45 & & - & - & - & - & - & - \\
\hline Bone & 9 & 0.92 & 2 & 0.64 & & - & - & - & - & - & - \\
\hline Connective tissue & 27 & 1.21 & 5 & 0.93 & & - & - & - & - & - & - \\
\hline Metastases & 60 & $0 \cdot 71^{\star}$ & 24 & 1.43 & & - & - & - & - & - & - \\
\hline Other and unspecified sites & 29 & 0.95 & 8 & 1.33 & & - & - & - & - & - & - \\
\hline Non-Hodgkin's lymphoma & 120 & $1 \cdot 01$ & 27 & 1.02 & $\|$ & 9 & 1.59 & $1 \cdot 27$ & 5 & 1.67 & 1.34 \\
\hline Hodgkin's disease & 27 & $0.63^{\star}$ & 13 & 1.01 & & 10 & $2.91 \star$ & $2 \cdot 33^{\star}$ & 1 & 0.41 & 0.33 \\
\hline Multiple myeloma & 63 & 0.96 & 20 & $1.57^{\star}$ & & 1 & 0.31 & 0.25 & 0 & 0 & 0.00 \\
\hline Leukaemia & 145 & 0.92 & 33 & 0.98 & & 12 & 0.81 & 0.65 & 8 & 1.09 & 0.87 \\
\hline Mycosis fungoides & 4 & 0.82 & 0 & 0.00 & ๆ & - & - & - & - & - & - \\
\hline
\end{tabular}

Adjusted MOR = Mortality odds ratios adjusted to allow for the low general mortality of farmers (see materials and methods).

${ }^{\star} \mathrm{p}<0.05$.

tIncludes peritoneum and unspecified digestive.

†Included in small intestine.

§Includes malignant and benign tumours of the nervous system (ICD-9: 191, 192, 225, 237.5, 237.9, 239.6).

IIncludes mycosis fungoides.

qIncluded in non-Hodgkin's lymphoma.

Obs $=$ No of observed cases.

1970 census data and the Danish Cancer Register. Cancer sites, coded according to the International Classification of Diseases, seventh revision (ICD-7) (1970-1977) and ICD-0 (1978-1980), were assembled in 47 standard diagnostic groups. ${ }^{1}$

In the Italian study a cohort of farmers of both sexes aged 18 to 74 years was identified from the 1981 census and the mortality was followed up for six months (11 November 1981 to 11 April 1982). Job title and economic activity were coded according to the Italian classifications. ${ }^{2}{ }^{3}$ For the present study two job titles were considered: self-employed farmers (code 3.1) and employees (codes 3.2 and 3.3). The
Italian classification of occupations does not include a title for family workers in agriculture and criteria for defining self employed farmers among women were not strict.

Cancer deaths in the Italian cohort were identified through record linkage between death certificates and the 1981 census data. The linkage key was provided by the local population registries where the death occurred. Cooperation was provided by $96 \%$ of the registries $(90 \%$ of the deaths). The proportion of non-linked deaths was $16 \%$ resulting in an overall $75 \%(90 \% \times 84 \%)$ of successful matching. Further details are described elsewhere. ${ }^{4}$ Causes of death, 
Table 2 Standardised incidence ratios (SIRs) and mortality odds ratios (MORs) of cancer among female Danish and Italian farmers

\begin{tabular}{|c|c|c|c|c|c|c|c|c|c|c|c|c|c|}
\hline \multirow[b]{3}{*}{ Cancer sites } & \multicolumn{6}{|c|}{ Denmark } & & \multicolumn{6}{|c|}{ Italy } \\
\hline & \multicolumn{2}{|c|}{ Self employed } & \multicolumn{2}{|c|}{ Family worker } & \multicolumn{2}{|c|}{ Employees } & & \multicolumn{3}{|c|}{ Self employed } & \multicolumn{3}{|c|}{ Employees } \\
\hline & Obs & $S I R$ & Obs & $S I R$ & Obs & SIR & & Obs & $M O R$ & $\begin{array}{l}\text { Adjusted } \\
M O R\end{array}$ & Obs & $M O R$ & $\begin{array}{l}\text { Adjusted } \\
M O R\end{array}$ \\
\hline Lip & 0 & 0.00 & 0 & 0.00 & 0 & 0.00 & & & & . & & & \\
\hline Tongue & 0 & 0.00 & 0 & 0.00 & 0 & 0.00 & & & & & & & \\
\hline Salivary glands & 0 & 0.00 & 4 & $1 \cdot 11$ & 1 & $3 \cdot 33$ & & 0 & 0 & 0.00 & 0 & 0 & 0.00 \\
\hline Mouth & 0 & 0.00 & 4 & 0.69 & 0 & 0.00 & & & & & & & \\
\hline Pharynx & 0 & 0.00 & 5 & 0.90 & 0 & 0.00 & & & & & & & \\
\hline Oesophagus & 1 & $1 \cdot 35$ & 2 & 0.36 & 0 & 0.00 & & 0 & 0 & 0.00 & 0 & 0 & 0.00 \\
\hline Stomach & 5 & $1 \cdot 01$ & 27 & $0 \cdot 70$ & 5 & 1.66 & & 8 & $1 \cdot 26$ & 0.88 & 2 & 0.60 & 0.42 \\
\hline Small intestine & 0 & 0.00 & 5 & $1 \cdot 10$ & 0 & 0.00 & $\dagger$ & 1 & $0 \cdot 36$ & $0 \cdot 25$ & 1 & 0.79 & 0.55 \\
\hline Colon & $\begin{array}{r}14 \\
5\end{array}$ & 0.89 & 112 & 0.93 & 2 & $0.21^{\star}$ & & 6 & 0.89 & 0.62 & 1 & 0.31 & $0 \cdot 22$ \\
\hline $\begin{array}{l}\text { Rectum } \\
\text { Liver }\end{array}$ & $\begin{array}{l}5 \\
0\end{array}$ & $\begin{array}{l}0.56 \\
0.00\end{array}$ & $\begin{array}{r}55 \\
5\end{array}$ & $\begin{array}{l}0.80 \\
0.54\end{array}$ & 2 & $0 \cdot 38$ & & 0 & & & & & \\
\hline Gallbladder & 7 & $\begin{array}{l}0.00 \\
2 \cdot 66^{\star}\end{array}$ & 17 & $\begin{array}{l}0.54 \\
0.95\end{array}$ & $\begin{array}{l}0 \\
1\end{array}$ & $\begin{array}{l}0.00 \\
0.73\end{array}$ & & 3 & 0.53 & $0 \cdot 37$ & 3 & $1 \cdot 37$ & 0.96 \\
\hline Liver not specified as primary & y 1 & $2 \cdot 27$ & 3 & 0.83 & 0 & 0.00 & & & & & & & \\
\hline Pancreas & 7 & $1 \cdot 20$ & 27 & $0 \cdot 66^{\star}$ & 4 & $1 \cdot 27$ & & 0 & 0 & $0 \cdot 00$ & 0 & 0 & 0.00 \\
\hline \multicolumn{14}{|l|}{ Peritoneum and unspecified } \\
\hline digestive & 1 & $2 \cdot 13$ & 5 & $1 \cdot 15$ & 0 & 0.00 & $\ddagger$ & - & - & - & - & - & - \\
\hline Nasal cavities and sinuses & 1 & 3.45 & 0 & 0.00 & 0 & 0.00 & & 0 & 0 & 0.00 & 0 & 0 & 0.00 \\
\hline Larynx & 0 & 0.00 & 1 & $0 \cdot 15^{\star}$ & 0 & 0.00 & & 0 & 0 & 0.00 & 0 & 0 & 0.00 \\
\hline Lung & 3 & $0 \cdot 24^{\star}$ & 51 & $0.45^{\star}$ & 6 & 0.68 & & 5 & 0.91 & 0.64 & 5 & $2 \cdot 12$ & 1.48 \\
\hline Pleura & 0 & 0.00 & 2 & 0.69 & 0 & 0.00 & & 0 & 0 & 0.00 & 0 & 0 & 0.00 \\
\hline Lung not specified as primary & y 0 & 0.00 & 0 & 0.00 & 0 & 0.00 & & - & - & - & - & - & - \\
\hline \multicolumn{14}{|l|}{ Mediastinum and } \\
\hline unspecified respiratory & 0 & 0.00 & 1 & $0 \cdot 75$ & 0 & 0.00 & & 0 & 0 & 0.00 & 0 & 0 & 0.00 \\
\hline Breast & 41 & $0 \cdot 87$ & 429 & $0 \cdot 81^{\star}$ & 25 & $0 \cdot 60^{\star}$ & & 19 & 0.91 & 0.64 & 5 & $0 \cdot 37^{\star}$ & $0 \cdot 26^{\star}$ \\
\hline Cervix uteri & 7 & $0.47^{\star}$ & 100 & $0.50^{\star}$ & 12 & 0.77 & 1 & & & & & & \\
\hline Corpus uteri & 8 & 0.56 & 103 & $0.82^{\star}$ & 9 & 0.91 & \} & 6 & 1.02 & 0.71 & 5 & $1 \cdot 75$ & $1 \cdot 23$ \\
\hline Uterus other and unspecified & 0 & 0.00 & 0 & 0.00 & 0 & 0.00 & & & & & & & \\
\hline Ovary & 12 & 0.90 & 104 & $0 \cdot 78^{\star}$ & 5 & 0.48 & & 3 & 0.56 & 0.39 & 1 & $0 \cdot 31$ & $0 \cdot 22$ \\
\hline \multicolumn{14}{|l|}{ Other and unspecified } \\
\hline genital & 2 & $1 \cdot 12$ & 11 & 0.67 & 1 & 0.77 & & - & - & - & - & - & 一 \\
\hline Kidney & 4 & 0.90 & 30 & 0.78 & 3 & 1.00 & & 1 & 0.86 & 0.60 & 2 & $4 \cdot 23^{\star}$ & $2 \cdot 96$ \\
\hline Bladder & 1 & $0 \cdot 19$ & 25 & $0.61 \star$ & 2 & 0.63 & & 0 & 0 & 0.00 & 1 & $5 \cdot 12$ & 3.58 \\
\hline Melanoma of skin & 5 & $1 \cdot 17$ & 32 & $0 \cdot 56^{\star}$ & 7 & $1 \cdot 51$ & & 1 & 0.95 & 0.67 & 2 & $2 \cdot 31$ & $1 \cdot 62$ \\
\hline Other skin & 5 & $0 \cdot 31^{\star}$ & 90 & $0.61^{\star}$ & 10 & 0.86 & & - & - & - & - & - & - \\
\hline Eye & 0 & 0.00 & 8 & $1 \cdot 87$ & 0 & 0.00 & & - & - & - & - & - & 一 \\
\hline Brain and nervous system & 5 & 0.95 & 51 & 0.92 & 2 & 0.45 & $\S$ & 1 & $0 \cdot 27$ & $0 \cdot 19$ & 2 & $1 \cdot 02$ & $0 \cdot 71$ \\
\hline Thyroid & 1 & $1 \cdot 27$ & 15 & $1 \cdot 67^{\star}$ & 1 & $1 \cdot 35$ & & 一 & - & - & - & - & - \\
\hline Endocrine glands & 0 & 0.00 & 2 & 0.84 & 0 & 0.00 & & - & - & - & - & - & - \\
\hline Bone & 0 & 0.00 & 1 & 0.56 & 1 & $6 \cdot 25^{\star}$ & & - & - & - & - & - & - \\
\hline Connective tissue & 0 & 0.00 & 5 & 0.96 & 1 & $2 \cdot 38$ & & - & - & - & - & - & - \\
\hline Metastases & 1 & 0.52 & 15 & $0 \cdot 84$ & 2 & 1.43 & & - & - & - & - & - & - \\
\hline Other and unspecified sites & 1 & 0.82 & 11 & $1 \cdot 14$ & 1 & 1.35 & & - & - & - & - & - & - \\
\hline Non-Hodgkin's lymphoma & 4 & $1 \cdot 29$ & 21 & $0 \cdot 78$ & 1 & 0.47 & $\|$ & 1 & 0.92 & 0.64 & 2 & $3 \cdot 28$ & $2 \cdot 30$ \\
\hline Hodgkin's disease & 1 & $1 \cdot 11$ & 9 & 0.92 & 1 & $1 \cdot 22$ & & 1 & $1 \cdot 87$ & $1 \cdot 31$ & 0 & 0 & 0.00 \\
\hline Multiple myeloma & 6 & $3 \cdot 30^{\star}$ & 16 & $1 \cdot 32$ & 0 & 0.00 & & 1 & $1 \cdot 50$ & $1 \cdot 05$ & 0 & 0 & 0.00 \\
\hline Leukaemia & 8 & $2 \cdot 22^{\star}$ & 27 & 0.89 & 3 & $1 \cdot 25$ & & 5 & $1 \cdot 71$ & $1 \cdot 20$ & 4 & $2 \cdot 22$ & $1 \cdot 55$ \\
\hline Mycosis fungoides & 0 & 0.00 & 0 & 0.00 & 0 & 0.00 & 9 & - & - & - & - & - & - \\
\hline
\end{tabular}

Adjusted MOR = Mortality odds ratios adjusted to allow for the low general mortality of farmers (see materials and methods).

${ }^{\star} \mathrm{p}<0 \cdot 05$.

tIncludes peritoneum and unspecified digestive.

+Included in small intestine.

$\S$ Includes malignant and benign tumours of the nervous system (ICD-9: 191, 192, 225, 237.5, 237.9, 239.6).

Includes mycosis fungoides.

Included in non-Hodgkin's lymphoma.

Obs $=$ No of observed cases.

coded according to ICD-9, were grouped in 30 categories.

\section{STATISTICAL ANALYSIS}

For Danish data, the number of expected cancer cases was calculated by multiplying the person years at risk during the 10 year follow up period in each five year age group with the site specific incidence rates calculated in the same way for all persons econ- 
puted for each cancer site, according to Mantel and Haenszel, ${ }^{5}$ and adjusted for age in three groups (18$44,45-64,65-74)$. Subjects dying from all other causes of death were used as referents. Test based $95 \%$ confidence intervals ( $95 \%$ CIs) were computed according to Miettinen. ${ }^{6}$ Moreover, to allow for the low overall mortality, we multiplied these MORs (95\% CIs) with the ratio of overall mortality in agriculture, forestry, and fishing and overall mortality in all other branches (adjusted for the same age classes, 0.8 for men and 0.7 for women).

\section{Results}

EPITHELIAL CANCERS

Table 1 presents relative risk (RR) estimates (SIRs and MORs respectively) for each cancer site among Danish and Italian male farmers.

A reduced risk was found among both groups for cancers of the lung, bladder, small intestine, colon, rectum, and prostate (statistically significant in the Danish data and, for lung cancer, also in the Italian data). The reduction was greater among self employed farmers for lung cancer and among employees for cancer of colon and rectum. The RR of stomach cancer was also similar, near unity with a slight excess among employees, for both Italian and Danish farmers.

For brain cancer SIRs were also around unity in Danish data whereas the overall MOR for Italian male farmers was $0 \cdot 54$. The Italian result was statistically significant $(\mathrm{p}<0.05)$.

Significant risk reductions were found among Danish men for cancers of the pancreas and larynx but not among the Italians.

In Denmark the SIR for oesophageal cancer among self employed male farmers was reduced. On the other hand, self employed Italian male farmers experienced an increased mortality from this cancer.

The situation was similar for women (table 2), taking into account that numbers were small for the Italians and with the exception of an increased risk (but based on five observed cases only) of lung cancer among Italian employees. Risk for breast cancer was reduced in both Italian and Danish farmers, the lowest risk being for employees.

The RR of cancer of the cervix and (to a smaller extent) corpus uteri, was less than unity for Danish farmers. The $R R$ for cancer of the uterus was around one among Italian women.

\section{CANCERS OF THE LYMPHOPOIETIC SYSTEM}

A significant reduction in the risk of Hodgkin's disease among male self employed farmers emerged from the Danish data. On the other hand a significant excess was found among Italian self employed men.

A slight excess risk of non-Hodgkin's lymphoma was seen both in men and women in Italian data, although based, especially among women, on small numbers. No excess was found among Danish farmers in general, only for the small group of self employed women.

Danish data showed no excess of leukaemia among both men and women working in farms where the man is the farmer. In a few farms in which the owner is a woman, a high risk was found for women, although this result is based on eight cases only. Italian data are similar in that no excess was found among men but the risk was increased among women working in agriculture. In the Danish data the RR of multiple myeloma was near one for self employed men, there was a slight excess for male employees and female family workers, and a strong excess among self employed women. Italian data were uninformative, given the small number of cases.

Table 3 reports the specific occupations related to agriculture and showing an excess risk (observed $>$ (expected + expected $\left.^{1 / 2}\right)$ ) of cancers of the lymphopoietic system in Denmark. Many of them (self employed/special farms, tractor driver/agricultural services, cowman) entail animal handling. Self employed veterinarians were also at high risk of leukaemia and multiple myeloma. It is also interesting that, in Italy, the only two cases (one man and one woman) of myeloma were found in persons concerned with animal feeding despite the fact that a total of only 48 deaths occurred in this category among men and only five deaths among women.

\section{Discussion}

For epithelial cancers, the strongest difference bet-

Table 3 Specific occupations in agriculture showing an excess risk of lymphatic cancers in Denmark

\begin{tabular}{|c|c|c|}
\hline & Obs & SIR \\
\hline \multicolumn{3}{|l|}{ Men } \\
\hline $\begin{array}{l}\text { Non-Hodgkin's lymphoma: } \\
\text { Farm worker living on farm } \\
\text { Cowman } \\
\text { Self employed/special farms } \\
\text { Self employed/large farms }\end{array}$ & $\begin{array}{l}8 \\
6 \\
4 \\
4\end{array}$ & $\begin{array}{l}1.46 \\
3.02 \\
1.91 \\
2.46\end{array}$ \\
\hline $\begin{array}{l}\text { Hodgkin's disease: } \\
\text { Tractor driver/agricultural services }\end{array}$ & 2 & 4.50 \\
\hline $\begin{array}{l}\text { Multiple myeloma } \\
\text { Gardener's labourer } \\
\text { Cowman }\end{array}$ & $\begin{array}{l}6 \\
4\end{array}$ & $\begin{array}{l}2 \cdot 48 \\
4 \cdot 30\end{array}$ \\
\hline $\begin{array}{l}\text { Leukaemia } \\
\text { Self employed/ordinary farms } \\
\text { Self employed/special farms } \\
\text { Tractor driver/agricultural services }\end{array}$ & $\begin{array}{r}28 \\
5 \\
3\end{array}$ & $\begin{array}{l}1 \cdot 43 \\
1 \cdot 82 \\
4 \cdot 68\end{array}$ \\
\hline \multicolumn{3}{|l|}{ Women } \\
\hline $\begin{array}{l}\text { Multiple myeloma } \\
\text { Family worker/ordinary farms }\end{array}$ & 7 & $2 \cdot 11$ \\
\hline $\begin{array}{l}\text { Leukaemia } \\
\text { Family worker/gardening } \\
\text { Self-employed/ordinary farms }\end{array}$ & $\begin{array}{l}5 \\
4\end{array}$ & $\begin{array}{l}2 \cdot 47 \\
4 \cdot 45\end{array}$ \\
\hline
\end{tabular}

Obs $=$ No of observed cases. 
ween the two data sets concerns the risk of oesophageal cancer, which is reduced among Danish and increased among Italian male farmers. This last finding is at variance with the results of most reports from other countries where the risk of oesophageal cancer is generally reduced ${ }^{7-12}$ or near one. ${ }^{13-16}$ An exception is France where a higher incidence of oesophageal cancer among farmers has been reported. ${ }^{17}$ Although in the past, in both countries, cigarette consumption has been lower among farmers than in the general population, alcohol consumption has been higher than the national average among Italian male farmers, at least in the recent past. ${ }^{18}$ The difference in the risk of cancer of the larynx, another tobacco and alcohol related cancer (strongly reduced in Denmark and slightly reduced in Italy) and the excess risk for oesophageal cancer in France, where patterns of alcohol consumption are similar to the Italian ones, strengthen this interpretation.

Another major difference concerns the RR for brain cancer, which is around one among Danish farmers of both sexes and reduced among Italian men. This result is surprising because significantly ${ }^{11}{ }^{19}$ or nonsignificantly ${ }^{72} 14-162021$ increased risks of brain cancer have been reported by a number of studies on farmers. Moreover, an Italian hospital based casecontrol study ${ }^{22}$ found a significantly increased risk of glioma among subjects reporting as having ever worked as farmers, especially among insecticide and fungicide users. The discrepancy may be explained by a diagnostic bias in Italian farmers, who make less use of advanced diagnostic aids for brain cancer. Such a bias could affect a study based on death certificates but not a case-control study, where both cases and controls were inpatients in specialised neurological institutions.

The risk of the remaining epithelial cancers is similar in the two countries and it is in general consistent with previous results, except for stomach and prostate cancer. A statistically significant positive association between farming and prostatic cancer was reported by some previous studies s.9 $^{71} 12151923$ although there was no consistent evidence about the responsible exposure. ${ }^{24}$ Stomach cancer was traditionally associated with farming ${ }^{24}$ although a number of surveys concerning more recent calendar years found no excess. ${ }^{11} 19212526$ In southern Italy, where agriculture is by and large the most common activity, the incidence of stomach cancer is low, ${ }^{27}$ possibly because of a high consumption of fresh fruits and vegetables.

Differences in the RR of Hodgkin's disease (significantly increased among Italian men only) and non-Hodgkin's lymphoma (increased in Italian but not in Danish farmers) are remarkable.

In a review of cancer risk among farmers ${ }^{24}$ six studies out of 11 showed an excess risk of nonHodgkin's lymphoma. Specific agricultural activities and characteristics have been linked to non-Hodgkin's lymphoma, like working in orchards, ${ }^{19}$ chicken and pig production, and consumption of herbicides, insecticides, and fertilisers by county. ${ }^{12}$ Case-control studies $^{28-31}$ found an association between nonHodgkin's lymphoma and exposure to phenoxy herbicides although one study gave negative results ${ }^{32}$ and another found an increased risk only in specific subgroups. ${ }^{33}$ Although comparisons are difficult, the per capita consumption of phenoxy herbicides was much lower in Italy than in Denmark in the years between 1950 and 1970. It must, however, be considered that, in this period, treatments were performed mainly by professional applicators in Denmark and directly by farmers in Italy, and that the use of protective devices was low or absent in Italy. A high risk of soft tissue sarcoma, based on small numbers, was found in an Italian case-control study for female rice weeders occupied in $1950-5$ and potentially exposed to phenoxy herbicide. ${ }^{34}$

Existing data support an association between farming and Hodgkin's disease (in Blair's review ${ }^{24}$ six out of eight studies showed an RR above unity) but they do not provide clear cut evidence as to whether chemical or biological agents or both are involved. ${ }^{24} 35$ Therefore it is difficult to interpret the difference between Italian and Danish findings. It is remarkable, however, that in mortality ${ }^{36}$ and incidence ${ }^{8}$ data from Sweden SMR was 0.98 and SIR was 1.04. Differences in agricultural characteristics, related both to climate and to a later introduction of modern farming techniques (including protective devices) in Italy could be involved. In some recent studies ${ }^{122}$ the excess risk is concentrated in the older cohorts, suggesting that it is related to old agricultural activities.

Data on leukaemia from both countries are consistent in finding no excess risk among male farmers and an excess among self employed women; a similar pattern was found for multiple myeloma. Farms owned by women could have different characteristics and probably, in both countries, they more frequently manage activities like poultry and horse feeding. This would be consistent with results on specific activities at risk in Denmark, which often entail contact with animals, and with results on risk of myeloma in animal feeding in Italy. The virus of fowl leucosis was suggested as a possible agent of human leukaemia, ${ }^{37}$ although the epidemiological evidence is contradictory, ${ }^{24}$ and an association between chronic lymphatic leukaemia and contact with horses was reported in Sweden. ${ }^{38}$ It must, however, be noted that Danish family workers, who frequently feed poultry, do not have an increased risk of leukaemia.

Comparing occupational disease or mortality data from different countries is not always straightforward. The classifications, the structure of the labour market, and the lifestyle associated with specific 
occupations may differ. This exercise, which is a first attempt to analyse the Italian occupational mortality data, illustrates these problems.

We thank the Italian Central Institute of Statistics (ISTAT) and F Pagnanelli for providing the data base and $M$ De Maria for technical assistance. This study was performed in the framework of the EC concerted action on "Retrospective Evaluation of Occupational Exposures in Cancer Epidemiology."

Requests for reprints to: G Ronco, Unit of Cancer Epidemiology, Ospedale S Giovanni AS, via S Francesco da Paola 31, 10123 Turin, Italy.

1 Lynge E, Thygesen L. Occupational cancer in Denmark. Cancer Incidence in the 1970 census population. Scand J Work Environ Health 1990;16(suppl 2):1-35.

2 Istituto Centrale di Statistica. Classificazione delle attività economiche. Roma: ISTAT pubblicazioni Serie C Metodi e Norme No 8, 1981 .

3 Istituto Centrale di Statistica. Classificazione delle professioni. Roma: ISTAT pubblicazioni Serie C Metodi e Norme No 9, 1981 .

4 Istituto Centrale di Statistica. La mortalità differenziale secondo alcuni fattori socio-economici anni 1981-82. Roma: ISTAT pubblicazioni Note e relazioni 1990 No 2, 1990.

5 Mantel N, Haenszel W. Statistical aspects of the analysis of data from retrospective studies of disease. J Natl Cancer Inst 1959;122:710-48.

6 Miettinen OS. Estimability and estimation in case-referen studies. Am J Epidemiol 1976;103:226-35.

7 Buremeister LF. Cancer mortality in Iowa farmers 1971-1978. $J$ Natl Cancer Inst 1981;66:461-4.

8 Wilklund K, Einhorn J, Wennström S, Rapaport E. A Swedish cancer-environment register available for research. Scand $J$ Work Environ Health 1981;7:64-7.

9 Gallagher RP, Threfall WJ, Jeffries E, Band PR, Spinelli J, Coldman AJ. Cancer and aplastic anaemia in British Columbia farmers. J Natl Cancer Inst 1984;72:1311-15.

10 Walrath J, Rogot E, Murray J, Blair A. Mortality patterns among US veterans by occupation and smoking status. Washington DC: US Government Printing Office, 1985 (NIH publ No 85-2756).

11 Delzell E, Grufferman S. Mortality among white and non-white farmers in North Carolina, 1976-1978. Am J Epidemiol 1985;121:391-402.

12 Saftlas AF, Blair A, Cantor KP, Hanrahan LH, Anderson HA Cancer and other causes of death among Wisconsin farmers. Am J Ind Med 1987;11:119-29.

13 Versluys JJ. Cancer and occupation in the Netherlands. $B J$ Cancer 1949;3:162-85.

14 Decoufle P, Stanislawizyk K, Houten L, Bross IDJ, Viadana E. A retrospective survey of cancer in relation to occupation. Cincinnati: National Institute for Occupational Safety and Health, 1977 (DHEW (NIOSH) publ No 77-178).

15 Williams RR, Stegens NL, Goldsmith JR. Associations of cancer site and type with occupation and industry from the Third National Cancer Survey Interview. J Natl Cancer Inst 1977;59:1147-85.

16 Milham S Jr. Occupational mortality in Washington State,
1950-1979. Cincinnati: National Institute for Occupational Safety and Health, 1983. (DHHS (NIOSH) publ No 83-116.)

17 Cherie-Challine L, Pottier D, Gignoux M. Epidemiologie descriptive du cancer de l'oesophage dans le departement du Calvados: 520 cas (1978-1982). Gastroenterol Clin Biol 1988;12:126-32.

18 Istituto centrale di Statistica. Indagine statistica sulle condizioni di salute della popolazione e sul ricorso ai servizi sanitarinovembre 1983. ISTAT pubblicazioni. Note e relazioni anno 1986 N.1. Roma: 1986.

19 Reif J, Pearce N, Fraser J. Cancer risks in New Zealand farmers. Int J Epidemiol 1989;18:768-74.

20 Howe GR, Lindsay GP. A follow-up study of a ten percent sample of the Canadian labour force: I Cancer mortality in males, 1965-73. J Natl Cancer Inst 1983;70:37-44.

21 Rafnsson V, Gunnarsdóttir H. Mortality among farmers in Iceland. Int J Epidemiol 1989;18:146-51.

22 Musicco M, Sant M, Molinari S, Filippini G, Gatta G, Berrino F. A case-control study of brain gliomas and occupational exposure to chemical carcinogens: the risk to farmers. $A m J$ Epidemiol 1988;128:778-85.

23 Brownson RC, Reif JS, Chang JC, Davis JR. Cancer risks among Missouri farmers. Cancer 1989;64:2381-6.

24 Blair A, Malker H, Cantor KP, Burmeister L, Wilklund K. Cancer among farmers: a review. Scand $J$ Work Environ Health 1985;11:397-407.

25 Wilklund K, Holm LE. Trends in cancer risks among Swedish agricultural workers. J Natl Cancer Inst 1986;77:657-64.

26 Burmeister LF. Cancer in Iowa farmers: recent results. Am J Ind Med 1990;18:295-301.

27 Decarli A, La Vecchia C, Cislaghi C, Mezzanotte G, Marubini E. Descriptive epidemiology of gastric cancer in Italy. Cancer 1986;58:2560-9.

28 Hardell L, Eriksson M, Lenner P, Lundgren E. Malignant lymphoma and exposure to chemicals, especially organic solvents, chlorophenols, and phenoxy acids: a case-control study. Br J Cancer 1981;43:169-76.

29 Hoar SK, Blair A, Holmes FF et al. Agricultural herbicide use and risk of lymphoma and soft-tissue sarcoma. JAMA 1986;256:1141-7.

30 Persson B, Dalhander AM, Fredriksson M, Noorlind Brage $H$ Ohlson CG, Axelson O. Malignant lymphomas and occupational exposures. Br J Ind Med 1989;46:516-20

31 Zahm SH, Weisenburger DD, Pabbit PA, Sahal RC, Waught JB, Cantor KP, Blair A. A case-control study of nonHodgkin's lymphoma and the herbicide 2,4-D in Eastern Nebraska. Epidemiology 1990;1:349-56.

32 Pearce NE, Sheppard RA, Smith AH, Teague CA. NonHodgkin's lymphoma and farming: an expanded case-control study. Int J Cancer 1987;39:155-61.

33 Woods JS, Polissar L, Severson RK, Heuser LS, Kulander BG. Soft tissue sarcoma and non-Hodgkin's lymphoma in relation to phenoxyherbicide and chlorinated phenol exposure in Western Washington. J Natl Cancer Inst 1987;78:899-910.

34 Vineis P, Terracini B, Ciccone G, et al. Phenoxy herbicides and soft-tissue sarcomas in female rice weeders. A populationbased case-referent study. Scand J Work Environ Health 1987;13:9-17.

35 Pearce N, Reif JS. Epidemiological studies of cancer in agricultural workers. Am J Ind Med 1990;18:133-48.

36 Statistics Sweden. Dödsfalls registret 1961-1970. Stockholm: 1981.

37 Heath CW, Caldwell GG, Feorino PC. Viruses and other microbes. In: Fraumeni JF Jr, ed. Persons at high risk of cancer. New York: Academic Press, 1975, 241-56.

38 Flodin U, Fredriksson M, Persson B, Axelson O. Chronic lymphatic leukaemia and engine exhausts, fresh wood, and DDT: a case-referent study. Br J Ind Med 1988;45:33-8.

Accepted 22 July 1991 